\title{
Tear down academic paywall during pandemic
}

\author{
R. Costa-Pereira ${ }^{a}$ \\ ${ }^{a}$ Departamento de Biologia Animal, Instituto de Biologia, CP 6109, Universidade Estadual de Campinas - UNICAMP, \\ CEP 13083-970, Campinas, SP, Brasil \\ *e-mail: raulcpereira@gmail.com
}

Received: May 11, 2020 - Accepted: May 19, 2020 - Distributed: August 31, 2020

COVID-19 has transformed how academics work. Universities are shut, classes canceled or moved online, travel banned, and meetings postponed. Abandoning our offices to work from home while caring for our loved ones requires a complete and difficult change in our daily lives (Bodewits, 2020). Many of us are struggling to learn how to teach our students remotely while continuing to write and review manuscripts and grants outside of our usual working environment.

A major barrier to effectively working from home is paywall-restricted access to scientific papers, which represents $75 \%$ of all publications (Boudry et al., 2019). A considerable portion of academics, particularly those from developing nations, do not have access to paywalled papers from their homes. Excluding part of the academic community, which includes students working on their dissertations and thesis, from reading research publications during these unprecedented times is unacceptable. Sci-hub certainly helps to alleviate this problem (Bohannon, 2016), but we should not have to rely solely on this alternative in the midst of a pandemic. As a practical action to facilitate working from home, academic publishers should stop charging for access to papers during the pandemic. A simple and straightforward alternative would be allowing temporary view-only free access. Museums, educational institutions, and streaming services are already offering free access to their online content during self-quarantine.

COVID-19 is demanding massive lifestyle changes to mitigate its consequences, namely the cost of life. Many academic publishers are historically "socially distant" from the academic community, but it is time to understand the professional implications of this pandemic for academics and temporally tear down academic paywalls.

\section{References}

BODEWITS, K., 2020. Working from home because of COVID-19? Here are 10 ways to spend your time. Science. http://dx.doi. org/10.1126/science.caredit.abb7513.

BOHANNON, J., 2016. Who's downloading pirated papers? Everyone. Science, vol. 352, no. 6285, pp. 508-512. http://dx.doi. org/10.1126/science.352.6285.508. PMid:27126020.

BOUDRY, C., ALVAREZ-MUÑOZ, P., ARENCIBIA-JORGE, R., AYENA, D., BROUWER, N.J., CHAUDHURI, Z., CHAWNER, B., EPEE, E., ERRAÏS, K., FOTOUHI, A., GHARAIBEH, A.M., HASSANEIN, D.H., HERWIG-CARL, M.C., HOWARD, K., KAIMBO WA KAIMBO, D., LAUGHREA, P.-A., LOPEZ, F.A., MACHIN-MASTROMATTEO, J.D., MALERBI, F.K., NDIAYE, P.A., NOOR, N.A., PACHECO-MENDOZA, J., PAPASTEFANOU, V.P., SHAH, M., SHIELDS, C.L., WANG, Y.X., YARTSEV, V. and MOURIAUX, F., 2019. Worldwide inequality in access to full text scientific articles: the example of ophthalmology. PeerJ, vol. 7, pp. e7850. http://dx.doi.org/10.7717/peerj.7850. PMid:31687270. 